\title{
Seismic soil classification using a new standard proposal and comparison with the current standard for sites located in Reñaca and Concón
}

\author{
Clasificación sísmica del suelo con una nueva propuesta de norma y comparación con la
} norma actual para sitios localizados en Reñaca y Concón

Fecha de entrega: 20 de septiembre 2021 Fecha de aceptación: 11 de diciembre 2021

\section{Dennis Raddatz, Gonzalo Aguirre and Oscar Taiba}

Ferrara - Proyectos Especiales, Av. Ossa 235, oficina 1150, La Reina, RM de Santiago, Chile, dennis.raddatz@ferrara.cl, gonzalo.aguirre@ferrara.cl,oscartaiba@ferrara.cl

In Chile, to seismically classify a site where a structure is to be founded, the indications of the Chilean design code (NCh433 and DS61), have to be fulfilled. It is a requirement to have the average soil shear wave velocity of the upper $30 \mathrm{~m}$ of the site $\left(V_{s 30}\right)$, and laboratory or in-situ test results related with soil resistance such as: unconfined compression strength $\left(q_{w}\right)$, normalized standard penetration test resistance $\left(N_{l}\right)$ and/or soil undrained shear strength $\left(S_{u}\right)$. In the new classification proposal system (prNCh433, 2018), classification parameters are those that are related to seismic response at the ground surface of the site: $V_{s 30}$, and the predominant soil period $\left(T_{g}\right)$ estimated using the $H / V$ spectral ratio (method of Nakamura). On this article it is compared the classification requirements of the Chilean standard with main design codes and standards in the rest of the world. Also, fundamental periods of soil obtained from measurements carried out in Reñaca and Concón area, are used to seismically classify sites where soil mechanics reports are available. The classifications are undertaken with the new proposed classification standard and comparisons are made with the current classification. As part of this work, it is analyzed whether the sites maintain or change their seismic soil classification and the type of change they undergo. Finally, soil parameters that are determinants for the obtained soil classifications are identified

Keywords: seismic soil classification, $V_{s 30}$, soil fundamental period
En Chile, para clasificar sísmicamente un sitio donde se pretende fundar una estructura, se deben cumplir las disposiciones normativas (NCh433 y DS61), requiriéndose contar con la velocidad de onda de corte equivalente de los $30 \mathrm{~m}$ superiores del terreno $\left(V_{s 30}\right)$ y con propiedades asociadas a la resistencia del suelo como: compresión no-confinada $\left(q_{w}\right)$, indice de penetración estándar normalizado $\left(N_{I}\right)$ y/o resistencia no drenada del terreno $\left(S_{u}\right)$. En la nueva propuesta de clasificación (prNCh433, 2018), los parámetros de clasificación son aquellos que están relacionados con la respuesta sísmica en la superficie del sitio: $V_{s 30}, y$ el periodo predominante del suelo $\left(T_{g}\right)$ estimado mediante la razón espectral $\mathrm{H} / \mathrm{V}$ (método de Nakamura). En este trabajo se realiza una comparativa de los requisitos de clasificación de la normativa chilena con los principales códigos de diseño en el resto del mundo. Además, se utilizan mediciones del periodo predominante del suelo realizadas en la zona de Reñaca y Concón para clasificar sísmicamente los suelos donde actualmente existen informes de mecánica de suelos disponibles. Las clasificaciones se hacen con la nueva propuesta de clasificación y se realiza una comparación con la clasificación actual. Como parte de este trabajo, se analiza si los sitios mantienen o cambian su clasificación sísmica $y$ el tipo de cambio que experimentan. Finalmente, se identifican los parámetros del suelo que son determinantes para las clasificaciones obtenidas.

Palabras clave: clasificación sísmica del suelo, $V_{s 30}$, periodo predominante del suelo

\section{Introduction}

Currently in Chile to seismically classify a site where a structure will be founded, the standard NCh433 (2009) is used, which was modified by DS61 (2011), where it is indicated necessary to have the parameter of average soil shear wave velocity of the upper $30 \mathrm{~m}$ of the site $\left(V_{\mathrm{s} 30}\right)$, 
which, despite its limitations, is used in most seismic design codes in the world for seismic site classification (Verdugo and Valladares, 2016; Verdugo et al., 2019). In addition, to classify seismically a site, soil resistance parameters are needed, such as: unconfined compression strength $\left(q_{\mathrm{u}}\right)$, normalized standard penetration test resistance $\left(N_{1}\right)$ and/or soil undrained shear strength $\left(S_{\mathrm{u}}\right)$. The use of one parameter or another depends on the type of soil and the value of $V_{\mathrm{s} 30}$. In the new seismic classification proposal (prNCh433, 2018), the parameter $V_{\mathrm{s} 30}$ is maintained, and it is complemented with the predominant soil period $\left(T_{\mathrm{g}}\right)$. $T_{\mathrm{g}}$ provides information on the entire soil deposit, of all its thickness, when it is estimated using the H/V spectral ratio (Nakamura, 1989), considered a fast, simple and lowcost method (Leyton et al., 2012; Verdugo and Valladares, 2016). In the seismic soil classification proposal, both parameters obtained with geophysical methods will be used, which have the advantage that they provide information quickly and non-invasively at the sites, with small deformations of the soils both on the surface and in depth (Godoy et al., 2015; Mendoza et al., 2018). In this work, the requirements for the current seismic classification method and for the new seismic classification proposal in Chile are summarized.

There are different design codes, recommendations, or standards in the world to seismically classify a site. For this work, a review of the types of soils according to the seismic classification of different design codes in the world was carried out: Europe, USA, New Zealand, Japan and China. The soil parameters necessary to seismically classify the site in each case are indicated. A proportionally comparative table between design codes was elaborated, using the common parameter of $V_{\mathrm{s} 30}$. For the codes that do not include $V_{\mathrm{s} 30}$, a value of $V_{\mathrm{s}}$ equivalent to the predominant soil period was assigned, depending on the assumptions made for each case.

In this work, the seismic soil classifications of 55 sites are analyzed, of which their seismic classification with the current requirements is compared with the one obtained when applying the new classification proposal. The predominant soil period values were obtained from a seismic microzoning project for the Reñaca sector and Concón (north of Viña del Mar), where 142 predominant soil period measurements were made (Aguirre, 2021). Tables are provided summarizing the results and the justification is also indicated for the cases in which changes in the classification occurred. In addition, the classifications obtained with the classification proposal are graphically presented, analyzing the critical parameters for each type of classification. Finally, conclusions from the results are drawn.

\section{Seismic site classification requirements in Chile}

\section{Current seismic classification system}

The current design code for seismic soil classification is based on DS61 (2011). The main parameter for the seismic classification of soils corresponds to the average of soil shear wave velocity of the upper $30 \mathrm{~m}$ of the site, $V_{\mathrm{s} 30}$, which represents a stiffness parameter at low deformations of the upper soil stratum. In total, DS61 (2011) establishes five main types of soils and a special soil type. Table 1 presents a summary of the current requirements for seismic classification identifying the types of soils.

Table 1: Seismic classification requirements of current Chilean standard (DS61, 2011)

\begin{tabular}{|c|c|c|c|c|c|c|}
\hline \multicolumn{2}{|r|}{ Rock and soil type } & $\begin{array}{l}V_{\mathrm{s} 30} \\
\mathrm{~m} / \mathrm{s}\end{array}$ & $\mathrm{RQD}$ & $q_{\mathrm{u}}$ & $N_{1}$ & $S_{\mathrm{u}}$ \\
\hline A & $\begin{array}{l}\text { Rock, cemented } \\
\text { soils }\end{array}$ & $\geq 900$ & $\geq 50$ & $\geq 10$ & & \\
\hline B & $\begin{array}{l}\text { Soft or fractured } \\
\text { rock, very dense } \\
\text { or very stiff soil }\end{array}$ & $\geq 500$ & & $\geq 0.40$ & $\geq 50$ & \\
\hline $\mathrm{C}$ & Dense or stiff soil & $\geq 350$ & & $\geq 0.30$ & $\geq 40$ & \\
\hline $\mathrm{D}$ & $\begin{array}{l}\text { Medium dense or } \\
\text { medium stiff soil }\end{array}$ & $\geq 180$ & & & $\geq 30$ & $\geq 0.05$ \\
\hline E & $\begin{array}{l}\text { Soils of medium } \\
\text { consistency }\end{array}$ & $<180$ & & & $\geq 20$ & $<0.05$ \\
\hline $\mathrm{F}$ & Special soils & & & & & \\
\hline
\end{tabular}

RQD: rock quality designation

In summary, for each one of the soil type classification, the requirement of $V_{\mathrm{s} 30}$ must be met and also with the other indicated requirements. For a rock or soil classified as type A, it must be additionally considered RQD in rocks and $q_{\mathrm{u}}$ in cemented soils. For B and C soil types $N_{1}$ must be additionally considered in sands and $q_{\mathrm{u}}$ in fine soils. For $\mathrm{D}$ and $\mathrm{E}$ soil types it must be additionally considered $N_{1}$ in sands and $S_{\mathrm{u}}$ in the case of fine soils. There is an exception for A rock or soil type, where it can be classified as A only with shear wave velocity $V_{\mathrm{s}}$, if the entire profile in the upper $15 \mathrm{~m}$ is over $900 \mathrm{~m} / \mathrm{s}$. On the other hand, if a structure rests 
entirely on the bedrock and this meets the geotechnical characteristics of a soil classified as type A, regardless of the geotechnical characteristics over the foundation level, the site classifies as A soil type. In addition, for cases where only $V_{\mathrm{s} 30}$ measurements are available, the value of $V_{\mathrm{s} 30}$ is in the range of $\mathrm{B}, \mathrm{C}$ or $\mathrm{D}$ soil types, and shear wave velocity increases monotonically with depth, the soil is classified punishing in one level below with respect to the range of classification of that $V_{\mathrm{s} 30}$. It is important to clarify that, if $V_{\mathrm{s} 30}$ is in the range of a soil type, and the other parameters are in a lower soil type classification, the classification will correspond to the lowest one. In the case of $\mathrm{D}$ soil type, it is allowed to have a $N_{1}$ value of E soil type in $5 \mathrm{~m}$ within $30 \mathrm{~m}$. An exception to the previously described form of classification are gravel deposits from fluvial origin with a thickness greater than or equal to $30 \mathrm{~m}$ (measured from the ground level), which are classified into B soil type without the need to measure shear wave velocity, or to present a detailed stratigraphic description. The support to establish the presence of gravel of fluvial origin with a thickness greater than or equal to $30 \mathrm{~m}$, can be geological, or reliable and demonstrable information from similar close areas. F soil type corresponds to soils that present singularities in their geotechnical behaviour and therefore require special geotechnical studies. In this category, liquefiable soils, collapsible soils, organic soils, sensitive soils, peat, among others are considered (DS61, 2011).

\section{Proposed seismic classification system}

The geotechnical engineering committee of SOCHIGE (Sociedad Chilena de Geotecnia) worked on a new seismic soil classification proposal since 2013 (Ruz and Finn, 2019), through the norm committee prNCh433 (2018) was released. In this proposal, $V_{\mathrm{s} 30}$ as a classification parameter is maintained and the $\mathrm{H} / \mathrm{V}$ spectral ratios method is incorporated to estimate the predominant period of the soil $T_{\mathrm{g}}$ (Nakamura, 1989). This method is one of the most popular to evaluate site effects, it considers the quotient between the horizontal and vertical components of the ambient noise vibrations through micro-vibrations measured on the surface of a soil deposit (Lermo y Chávez-García, 1994; Chávez-García y Montalva, 2014; Pastén et al., 2015; Fernández et al., 2017). A minimum of 5 environmental vibration measurements of at least 30 min duration each are required to evaluate the $\mathrm{H} / \mathrm{V}$ spectral ratio (prNCh433, 2018). To find the predominant soil period, measurements should be interpreted following the criteria of SESAME (2004). Regarding the current design code, the five main soil types are the same with the same $V_{\mathrm{s} 30}$ range, also the special soil type is maintained.

Table 2 presents a summary of the new proposal for soil classification identifying the types of soils. To classify a site, this table must be used, considering $V_{\mathrm{s} 30}$ values of the site as the first requirement, establishing a first possible classification associated with that value. To ratify this classification, the fulfillment of the predominant period of the soil $T_{\mathrm{g}}$, determined for the site must be verified. In the event that this second requirement is not met because $T_{\mathrm{g}}$ is higher to the range associated to that $V_{\mathrm{s} 30}$, the first possible classification must be downgraded by one level (prNCh433, 2018).

Table 2: Seismic classification requirements of the proposed Chilean standard (prNCh433, 2018)

\begin{tabular}{|c|l|c|c|}
\hline \multicolumn{2}{|c|}{ Rock and soil type } & $\begin{array}{c}V_{\mathrm{s} 30} \\
\mathrm{~m} / \mathrm{s}\end{array}$ & $\begin{array}{c}T_{\mathrm{g}} \\
\mathrm{s}\end{array}$ \\
\hline A & Rock, cemented soils & $\geq 900$ & $\begin{array}{c}<0.15 \text { (or flat H/V } \\
\text { curve) }\end{array}$ \\
\hline B & $\begin{array}{l}\text { Soft or fractured rock, very } \\
\text { dense or very stiff soil }\end{array}$ & $\geq 500$ & $\begin{array}{c}<0.30 \text { (or flat H/V } \\
\text { curve) }\end{array}$ \\
\hline C & Dense or stiff soil & $\geq 350$ & $\begin{array}{c}<0.40 \text { (or flat } \mathrm{H} / \mathrm{V} \\
\text { curve) }\end{array}$ \\
\hline D & $\begin{array}{l}\text { Medium dense or medium } \\
\text { stiff soil }\end{array}$ & $\geq 180$ & $<1.00$ \\
\hline E & $\begin{array}{l}\text { Soils of medium } \\
\text { consistency }\end{array}$ & $<180$ & \\
\hline F & Special soils & & \\
\hline
\end{tabular}

Regarding the current classification system, a difference is made when rocks or materials with $V_{\mathrm{s}}>900 \mathrm{~m} / \mathrm{s}$ are found at a depth of less than $30 \mathrm{~m}\left(H_{\mathrm{r}}\right)$ measured from the ground surface, in this case the $V_{\mathrm{s} 30}$ parameter must be calculated considering only the terrain existing up to that depth. In this article, the change in seismic classification for using $V_{\mathrm{s}}\left(H_{\mathrm{r}}\right)$ in a depth of less than $30 \mathrm{~m}$, product of a deep soil layer with a shear wave velocity greater than $900 \mathrm{~m} / \mathrm{s}$, was not analyzed because there are few cases like this within the analyzed projects. Detailed depth velocity profile was not available in all cases, and the shear wave velocity variation with depth can be is greatly influenced by data processing (e.g. number of soil layers) or by the $V_{\mathrm{s}}$ measurement method (e.g. MASW, ReMi). 


\section{Worldwide seismic site classification stan- dards}

In Europe (Eurocode 8, 2004), five main types and two special types of soil are indicated. For the classification it is necessary to have average values of soil shear wave velocity of the upper $30 \mathrm{~m}$ of the site $V_{\mathrm{s} 30}$, standard penetration index $N_{1}$ and soil undrained shear strength $S_{\mathrm{u}}$.

In the USA (IBC, 2018), five main types and one special type of soil are indicated. For classification it is necessary to have $V_{\mathrm{s} 30}, q_{\mathrm{u}}, N_{1}$ and/or $S_{\mathrm{u}}$. Similar requirements to those of Chile in its current form of seismic soil classification.

In New Zealand (NZS 1170.5, 2004), five types of soils are indicated. On the one hand, it is necessary to have $V_{\mathrm{s} 30}$ and the unconfined compression strength for rocks. On the other hand, for soils it is necessary to have predominant period of the soil $T_{\mathrm{g}}$, standard penetration index, soil undrained shear strength, stratigraphy and average speed of shear wave propagation. This configuration of five types of soils and their characteristic parameters is also used in Australia (Kouretzis et al., 2014).

In Japan (JRA, 2012), three types of soils are indicated. For the classification it is necessary to have only the predominant period of the soil.

In China (GB 50011, 2010), five types of soils are indicated. For seismic soil classification it is necessary to have the average shear wave velocity.

Next, Table 3 compares the types of soils and shear wave propagation velocity associated with their respective classification. The velocity ranges are proportionally shown in the table to facilitate their comparison.

Table 3: Comparison of soil type classification and its shear wave velocity for different standards

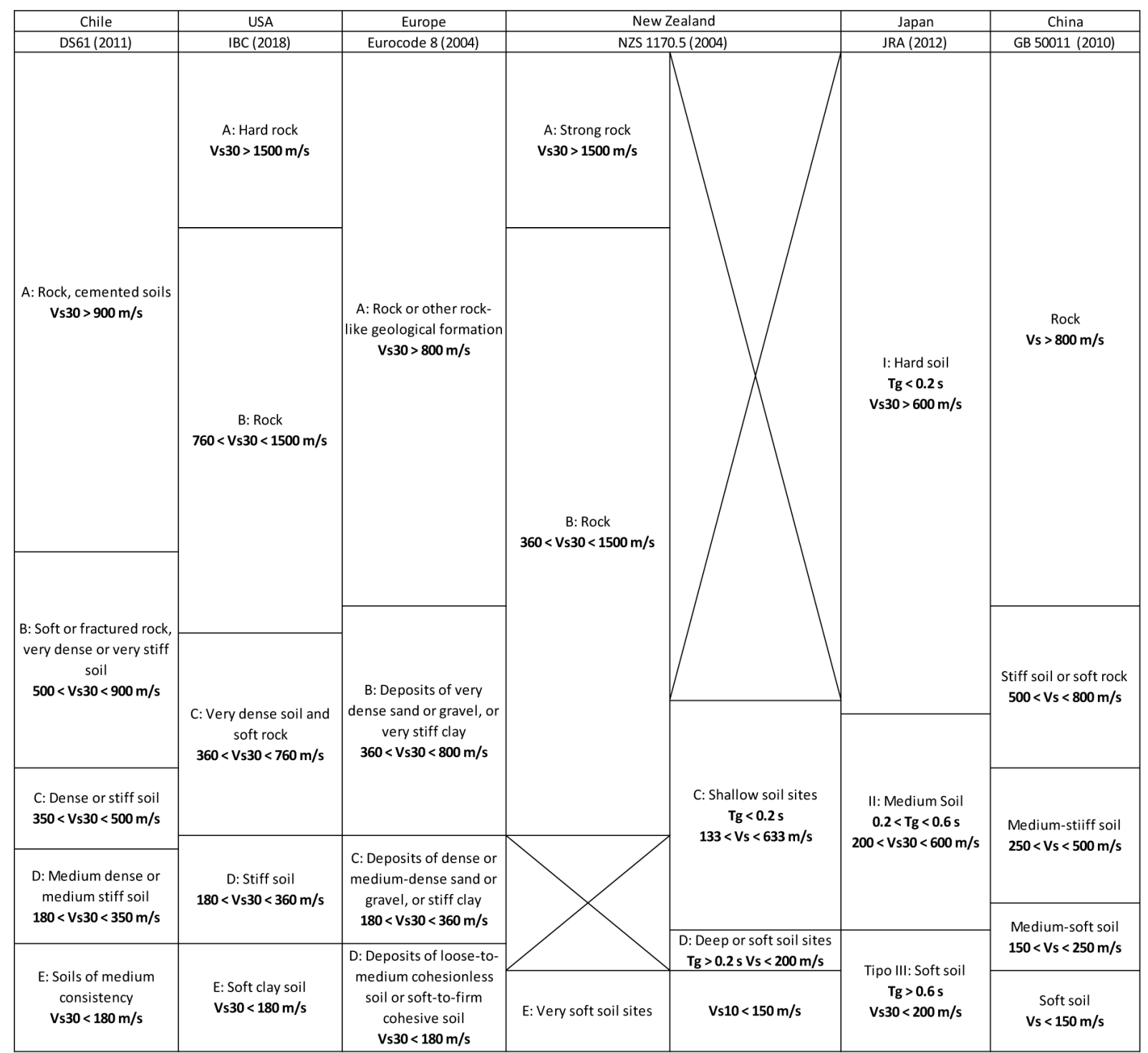


In the case of the New Zealand code, for C and D soil types, a fundamental soil period range is given as a parameter, so the velocity values indicated as limits correspond to estimates made for cohesive and non-cohesive soils, considering the travel time throughout the depth range of each soil type, not averaged over $30 \mathrm{~m}$ (Chaudhary, 2018). In the case of the Japanese code, as soils are neither described for each type nor are indicated $V_{\mathrm{s}}$ values, documents that describe each type of soil (DPWH, 2013), and associate in a simplified way a velocity value of $V_{\mathrm{s} 30}$ to each predominant period interval of the soil were used (Fukushima et al., 2007).

\section{Field measurements Methodology}

In order to carry out a seismic microzoning in the Reñaca area and Concón (north of Viña del Mar), 142 fundamental soil period measurements were performed (Aguirre, 2021). The measurements were distributed in areas where projects of all kinds have been and will be developed. Figure 1 shows predominant soil period measurement points and their values, with Concón presented in light blue, and Reñaca (Viña del Mar) in light green.

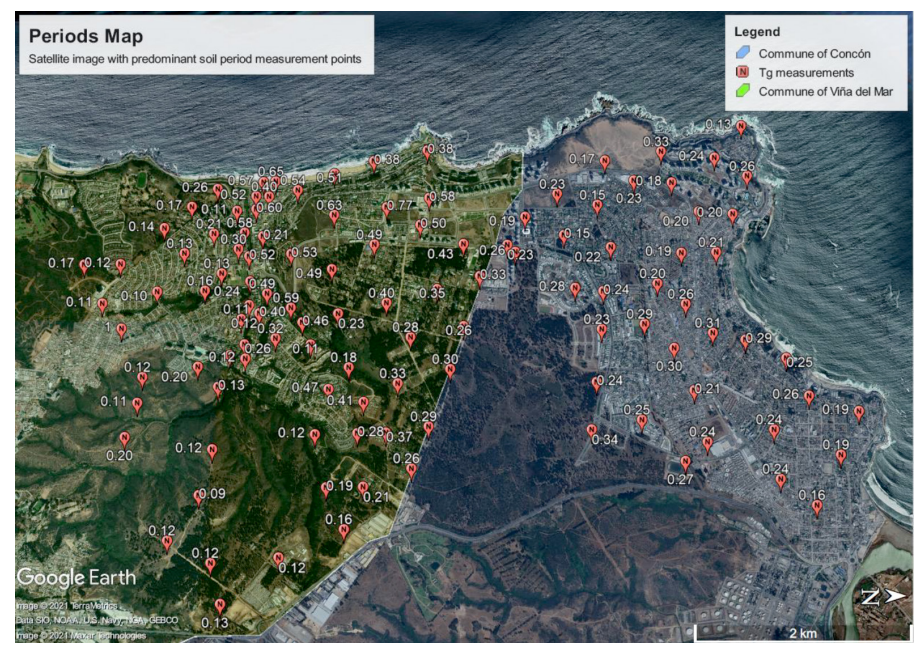

Figure 1: Data points of predominant soil period measurement in Reñaca and Concón

A database of 64 projects located in the area where the measurements of the fundamental soil period were performed was analyzed, and of which there was a soil mechanics report after the entry into force of DS61 (2011). The soil mechanics reports of the analyzed 64 projects were carried out by 10 different geotechnical companies. Of these measurements, 8 were discarded because the nearby measured periods did not meet the SESAME criteria, and another was discarded because the information in the soil mechanics report was incomplete. Within the SESAME criteria on the reliability of the results of the H/V curve, two categorizations are defined: a reliable $\mathrm{H} / \mathrm{V}$ curve and a clear H/V peak (SESAME, 2004). Two measurements did not meet the criterion for a reliable $\mathrm{H} / \mathrm{V}$ curve, one due to the presence of an external noise that was influencing the frequency band related to soil deposits, the other due to very irregular topographic conditions, in both, coherent results were not obtained. The other six measurements that were discarded did not meet the criterion for clear peak H/V. For four measurements the curves were flat, so as they did not have a clear peak, then a predominant period of the soil could not be identified and it could not be included in the analysis. For the other two measurements the curves did not have clear peaks around the amplitude and standard deviation of the curve.

Sites with irregular topography where local amplification phenomena may exist are neither covered by the current classification nor in the proposed classification. In the analyzed sectors there is a large topographic difference close to the sea at the east of Edmundo Eluchans Avenue, where the amplification effect has been verified in a particular project on this zone (Sucasaca and Saez, 2021). In the analysis carried out, the projects that were immediately just off the coast to the west of Edmundo Eluchans Avenue were discarded because of the SESAME criteria. Figure 2 shows the projects used in this work, the 55 projects with which they were finally worked are identified with blue color and the 9 discarded projects with red color.

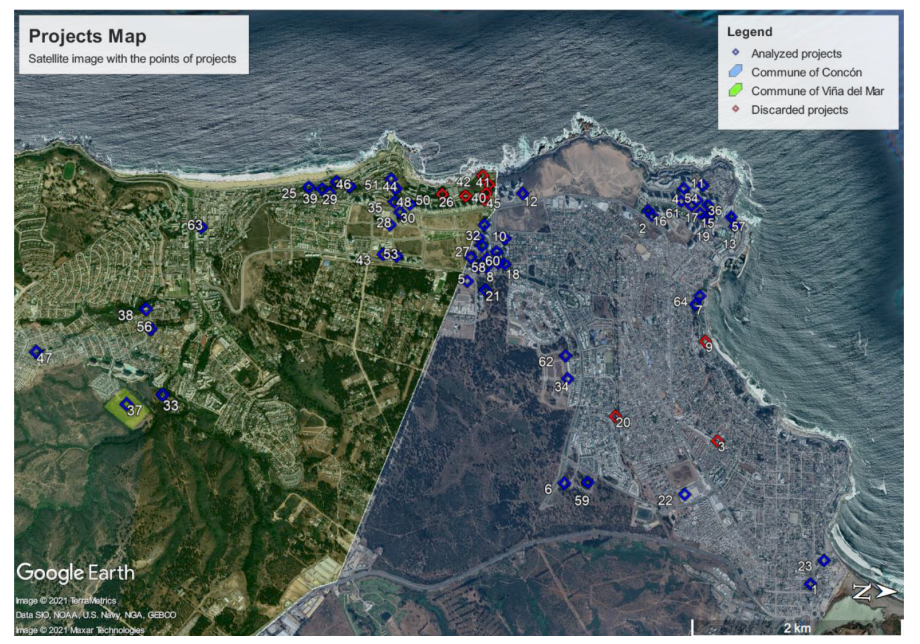

Figure 2: Selected and not selected data points used in this work 
For each of the 55 projects, the information in the soil mechanics reports was collected; soil type according to the seismic soil classification, $V_{\mathrm{s} 30}$ value of the project and the reason for the classification. For each project, a fundamental soil period $T_{\mathrm{g}}$ was associated, measured exclusively for that project or in the vicinity of its area (usually less than $150 \mathrm{~m}$ ). With the information of $V_{\mathrm{s} 30}$ and $T_{\mathrm{g}}$, each project was seismically classified considering the criteria of the proposed seismic classification system (prNCh433, 2018). The original classifications and those obtained from applying the new criteria were compared, and for the cases of differences, the reasons are analyzed. A graph of the obtained classifications was prepared, in order to explicitly appreciate the critical parameters in the different soil classification ranges.

\section{Results}

\section{Analysis of changes in the seismic soil classification}

For the 55 analyzed projects, the seismic soil classification obtained with the proposed classification was compared with that obtained with the current classification. Below there is a summary shown in Table 4 with all the changes and not-change of classification that occurred from this analysis.

Table 4: Comparison of seismic classification changes between proposed and current classification system

\begin{tabular}{|c|c|c|c|c|c|}
\hline $\begin{array}{l}\text { Comparison } \\
\text { result }\end{array}$ & $\begin{array}{c}\text { No. of } \\
\text { projects }\end{array}$ & $\begin{array}{c}\% \text { of } \\
\text { projects }\end{array}$ & $\begin{array}{l}\text { Type of } \\
\text { change }\end{array}$ & $\begin{array}{l}\text { No. of } \\
\text { projects }\end{array}$ & $\begin{array}{l}\% \text { of } \\
\text { projects }\end{array}$ \\
\hline \multirow{4}{*}{$\begin{array}{c}\text { Same } \\
\text { classification }\end{array}$} & \multirow{4}{*}{36} & \multirow{4}{*}{65.45} & $\mathrm{~B} \rightarrow \mathrm{B}$ & 4 & 7.27 \\
\hline & & & $\mathrm{C} \rightarrow \mathrm{C}$ & 28 & 50.91 \\
\hline & & & $\mathrm{D} \rightarrow \mathrm{D}$ & 3 & 5.45 \\
\hline & & & $\mathrm{E} \rightarrow \mathrm{E}$ & 1 & 1.82 \\
\hline \multirow{2}{*}{$\begin{array}{c}\text { Decrease } 1 \\
\text { level }\end{array}$} & \multirow{2}{*}{9} & \multirow{2}{*}{16.36} & $\mathrm{~B} \rightarrow \mathrm{C}$ & 1 & 1.82 \\
\hline & & & $\mathrm{C} \rightarrow \mathrm{D}$ & 8 & 14.55 \\
\hline \multirow{2}{*}{$\begin{array}{c}\text { Increase } 1 \\
\text { level }\end{array}$} & \multirow[b]{2}{*}{8} & \multirow{2}{*}{14.55} & $\mathrm{C} \rightarrow \mathrm{B}$ & 2 & 3.64 \\
\hline & & & $\mathrm{D} \rightarrow \mathrm{C}$ & 6 & 10.91 \\
\hline \multirow{2}{*}{$\begin{array}{c}\text { Increase } 2 \\
\text { levels }\end{array}$} & \multirow{2}{*}{2} & \multirow{2}{*}{3.64} & $\mathrm{D} \rightarrow \mathrm{B}$ & 1 & 1.82 \\
\hline & & & $\mathrm{E} \rightarrow \mathrm{C}$ & 1 & 1.82 \\
\hline
\end{tabular}

It is observed that most of the projects maintained their classification (65.45\%). Respect to the ones that changed, the projects that increase $(18.18 \%)$ are similar to those that decrease their classification (16.36\%).

Projects that increase their classification are explained by two reasons:
- They did not have SPT when they were classified with the current classification system, so their classifications had been punished.

- $\quad$ The SPT values presented low blows/ft in some soil strata, which when following the indications of DS61 (2011), made the classification highly influenced by these low SPT values. This was the reason for both cases in which the classification improved 2 levels.

Projects that decrease in their classification are explained by two reasons:

- Fundamental soil period is not part of the range of the original seismic soil classification, so the result of its measurement produces that the level in its classification must be punished because $T_{\mathrm{g}}$ has a value in a range of classification lower than the associated to the $V_{\mathrm{s} 30}$ value.

- In one case, the value of $V_{\mathrm{s} 30}$ was incorrectly calculated, when performing the correct calculation, it automatically lowered one classification level.

\section{Analysis of critical classification parameters}

In order to analyze the critical parameters of each classification, the seismic soil classifications obtained with the new classification proposal are plotted as shown in Figure 3. The way to graph them was that, for each of the 55 projects, their classification was graphed as a point, with the pair $\left(T_{\mathrm{g}}, V_{\mathrm{s} 30}\right)$, of a different colour depending on the soil classification type. In addition, lines were plotted on the graph that represents the lower shear wave velocity limit and the fundamental soil period range of each soil classification type according to the classification proposal. That is, for a project to have a classification it must be located above that classification line. If a point is under a classification line it means that it does not meet the $V_{\mathrm{s} 30}$ requirement and if it is to the right to its limit, it does not meet the $T_{\mathrm{g}}$ requirement.

Additionally, it is observed in Figure 3 that for the sites depending on their classification:

- Sites classified as B: points are heterogeneously distributed with more points near the lower shear wave velocity limit than the upper limit of the predominant soil period. 


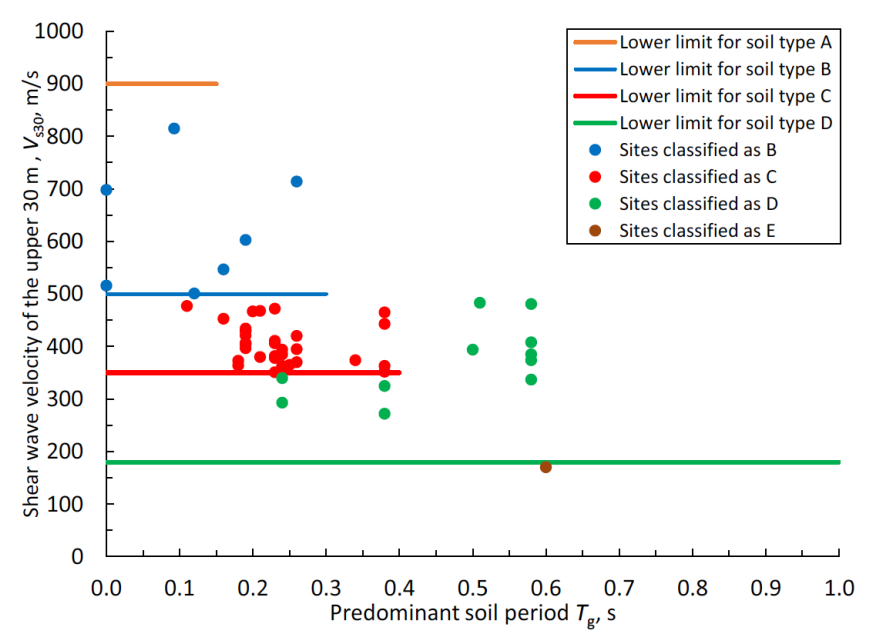

Figure 3: Results of the critical classification parameters for the proposed classification system

- Sites classified as C: there are many points near the classification limits of this type of soil, some close to the lower shear wave velocity limit, others near the upper limit of the predominant soil period and a few close to both limits. There are no points in this classification that have soil type B velocity and that have been punished for the predominant soil period.

- $\quad$ Sites classified as D: the points are located far from both limits, lower limit of shear wave velocity and upper limit of the predominant soil period. Most of the points in this classification have $\mathrm{C}$ soil type velocity, and were punished for the predominant soil period.

- $\quad$ Sites classified as E: the classification of this point is influenced by the shear wave velocity, since the velocity is in the range of soil type $\mathrm{E}$ but the predominant soil period is in the range of $\mathrm{D}$ soil type.

\section{Conclusions}

The soil parameters used in the seismic soil classification in Chile, both for the current design code and for the new classification proposal, are commonly used in different international design codes. The current seismic classification has many similarities with the design codes used in the USA and Europe, both in the parameters used as well as in defined types of soils and their $V_{\mathrm{s} 30}$ ranges. The classification proposal, like the Japanese or Chinese design codes, require only geophysical parameters, but it is pioneering since it requires two parameters unlike the other two codes where the classification is made with only one geophysical parameter. The seismic classification of a site with only geophysical methods will facilitate the seismic classification process, due to the practicality of taking these measurements and their data analysis, and the less invasive in the site compared to SPT tests or field sampling for laboratory tests. The fact that the values of $V_{\mathrm{s} 30}$ and the predominant period of the soil $T_{\mathrm{g}}$ are obtained directly from the analysis of measurements reduces the possibilities of different interpretations for the seismic soil classification. It is important to clarify that in situ geotechnical and laboratory tests will continue to be a fundamental contribution to build site stratigraphy and directly measure or estimate soil resistance parameters, and predict soil behaviour.

The new seismic site classification proposal can generate changes in the classification results, because the predominant soil period is a different parameter than the resistant parameters of the soil that are currently used. It is probable that a site that is classified with a value of $V_{\mathrm{s} 30}$ slightly above the lower limit of their range, may have a high probability also of being close to the upper limit of the period, going over the limit and therefore lowering a ranking value. On the other hand, because it is less expensive to measure $T_{\mathrm{g}}$ with respect to SPT, it can mean that for sites that today do not have an SPT for economic reasons, and therefore the current classification method punishes the classification obtained with $V_{\mathrm{s} 30}$, the predominant soil period parameter may allow maintaining the classification associated with that $V_{\mathrm{s} 30}$.

Most of the analyzed sites in this work present $V_{\mathrm{s} 30}$ in the range of $\mathrm{C}$ soil classification type, where the parameter of the predominant soil period confirms this classification or causes it to be punished to D type. With the new classification proposal, sites classified as D may increase, since from what was obtained in the analysis carried out, around $15 \%$ of sites fell from classification $\mathrm{C}$ to $\mathrm{D}$ as a result of a predominant period of the soil higher than 0.4 s. While $11 \%$ moved from $\mathrm{D}$ to $\mathrm{C}$ due to the fact that their original classification did not have SPT results, that is, for the latter case there is a high probability that these sites would have been previously classified as C if SPT results had been available. 


\section{References}

Aguirre, G. (2021). Microzonificación sísmica de las localidades de Reñaca y Concón mediante mediciones de espectro $H / V$ Nakamura. Civil Engineer degree project (in development), Universidad Técnica Federico Santa María, Chile

Chaudhary, M.T.A. (2018). A study on sensitivity of seismic site amplification factors to site conditions for bridges. Bulletin of the New Zealand Society for Earthquake Engineering 51(4), 197-211

Chávez-García, F.J. y Montalva, G.A. (2014). Efectos de sitio para Ingenieros Geotécnicos, estudio del valle Parkway. Obras y Proyectos 16, 6-30

DPWH (2013). LRFD bridge seismic design specifications. Department of Public Works and Highways DPWH guide specifications, Manila, Philippines

DS61 (2011). Decreto supremo 61 que aprueba reglamento que fija el diseño sísmico de edificios y deroga decreto 117, de 2010. Ministerio de la Vivienda y Urbanismo, MINVU, Santiago, Chile Eurocode 8 (2004). Design of structures for earthquake resistance. Part 1: General rules, seismic actions rules for buildings. European Committee for Standardization, Brussels, Belgium

Fernández, J., Pastén, C., Ruiz, S. y Leyton, F. (2017). Estudio de efectos de sitio en la Región de Coquimbo durante el terremoto de Illapel Mw 8.3 de 2015. Obras y Proyectos 21, 20-28

Fukushima, Y., Bonilla, L.F., Scotti, O. and Douglas, J. (2007). Site classification using horizontal-to-vertical response spectral ratios and its impact when deriving empirical ground-motion prediction equations. Journal of Earthquake Engineering 11(5): $712-724$

GB 50011 (2010). Code for seismic design of building. Ministry of Housing and Urban-Rural Development MoHURD, National Standard of the People's Republic of China, Beijing, China

Godoy, C., González, L. y Sáez, E. (2015). Importancia de la velocidad de onda de corte y del período predominante para la evaluación de la respuesta de sitio en Santiago. Obras y Proyectos 17, 61-67

IBC (2018). International building code. Chapter 16: Structural design. International Code Council. California, USA

JRA (2012). Specification for highway bridges. Part V: seismic design. Japan Road Association, Tokyo, Japan
Kouretzis, G.P., Masia, M.J. and Allen C. (2014). Structural design codes of Australia and New Zealand: seismic actions. Encyclopedia of Earthquake Engineering, Beer, M., Kougioumtzoglou, I., Patelli, E. and Au, I.K. (eds.), Springer, Berlin, Germany

Lermo, J. and Chávez-García, F.J. (1994). Are microtremors useful in site response evaluation?. Bulletin of the Seismological Society of America 84(5), 1350-1364

Leyton, F., Montalva, G. and Ramírez, P. (2012). A preliminary study of seismic microzonation of Concepción based on microtremors, geology and damages patterns. Obras y Proyectos 11, 40-46 Mendoza, L., Ayala, F., Fuentes, B., Soto, V., Sáez, E., Yañez, G., Montalva, G., Ramírez, P., Gález, C., Sepúlveda, N., Lazo, I. y Ruiz, J. (2018). Estimación cuantitativa de la amenaza sísmica en base a métodos geofísicos: aplicación a las localidades costeras del segmento Los Vilos - San Antonio. X Congreso Chileno de Ingeniería Geotécnica, Valparaíso, Chile

Nakamura, Y. (1989). A method for dynamic characteristics estimations of subsurface using microtremors on the ground surface. Q. Rep. Railway Tech. Res. Inst. Japan 30, 25-33

prNCh433 (2018). Diseño sísmico de edificios. Comité de anteproyecto de norma.

NCh433 (2009). Diseño sísmico de edificios. Instituto Nacional de Normalización INN, Santiago, Chile

NZS 1170.5 (2004). Structural design actions - Part 5: Earthquake design actions. New Zealand Standard. New Zealand

Pastén, C., Lezana, F., Leyton, F. y Ruiz, S. (2015). Razones espectrales $\mathrm{H} / \mathrm{V}$ de una red temporal de estaciones sismológicas en la Cuenca de Santiago - Resultados preliminares. Congreso Chileno de Sismología e Ingeniería Sísmica, Santiago, Chile

Ruz, F. and Finn, W.D.L. (2019). New Chilean seismic code and the use of Nakamura period for assessing damage potential. $7^{\text {th }}$ International Conference on Earthquake Geotechnical Engineering for Protection and Development of Environment and Constructions, Silvestri and Moraci (eds.), Associazione Geotecnica Italiana, Rome, Italy, CRC Press, 4760-4767

SESAME (2004). Guidelines for the implementation of the H/V spectral ratio technique on ambient vibrations. Measurements, processing and interpretation. Site EffectS assessment using AMbient Excitations SESAME European Research Project, France 
Sucasaca, J. and Saez, E. (2021). Topographical and structuresoil-structure interaction effects on dynamic behavior of shearwall buildings on coastal scarp. Engineering Structures 247, 113113

Verdugo, R., Ochoa-Cornejo, F., Gonzalez, J. and Valladares, G. (2019). Site effect and site classification in areas with large earthquakes. Soil Dynamics and Earthquake Engineering 126, 105071

Verdugo, R. y Valladares, G. (2016). Análisis de registros chilenos y periodo predominante del sitio. IX Congreso Chileno de Ingeniería Geotécnica, Valdivia, Chile 